IZA DP No. 8172

Surprising Selection Effects in the UK Car Insurance Market

Edmund Cannon

Giam Pietro Cipriani

Katia Bazar-Rosen

May 2014 


\title{
Surprising Selection Effects in the UK Car Insurance Market
}

\author{
Edmund Cannon \\ University of Bristol \\ Giam Pietro Cipriani \\ University of Verona \\ and IZA \\ Katia Bazar-Rosen \\ University of Bristol \\ Discussion Paper No. 8172 \\ May 2014 \\ IZA \\ P.O. Box 7240 \\ 53072 Bonn \\ Germany \\ Phone: +49-228-3894-0 \\ Fax: +49-228-3894-180 \\ E-mail: iza@iza.org
}

Any opinions expressed here are those of the author(s) and not those of IZA. Research published in this series may include views on policy, but the institute itself takes no institutional policy positions. The IZA research network is committed to the IZA Guiding Principles of Research Integrity.

The Institute for the Study of Labor (IZA) in Bonn is a local and virtual international research center and a place of communication between science, politics and business. IZA is an independent nonprofit organization supported by Deutsche Post Foundation. The center is associated with the University of Bonn and offers a stimulating research environment through its international network, workshops and conferences, data service, project support, research visits and doctoral program. IZA engages in (i) original and internationally competitive research in all fields of labor economics, (ii) development of policy concepts, and (iii) dissemination of research results and concepts to the interested public.

IZA Discussion Papers often represent preliminary work and are circulated to encourage discussion. Citation of such a paper should account for its provisional character. A revised version may be available directly from the author. 


\section{ABSTRACT}

\section{Surprising Selection Effects in the UK Car Insurance Market ${ }^{*}$}

We document a large and persistent anomaly in the UK car insurance market over the period 2012-13: insurance companies charged a higher premium for third-party (liability) insurance than comprehensive insurance (which includes third-party). Furthermore, some companies charged higher prices for comprehensive policies with larger deductibles. This evidence suggests both that consumers are too confused or too poorly informed to arbitrage and that sellers of car insurance do not implement the incentive-compatibility constraints at the heart of the adverse-selection model of insurance. This particular insurance market is much less sophisticated than that characterised by modern microeconomic theory.

JEL Classification: D82, G22

Keywords: car insurance, adverse selection, bounded rationality

Corresponding author:

Giam Pietro Cipriani

University of Verona

Department of Economics

Via dell'Artigliere 19

37129 Verona

Italy

E-mail: giampietro.cipriani@univr.it

\footnotetext{
* We thank Louise Smith for collecting the data; Stuart Bailey for invaluable advice in describing the process by which customers actually purchase car insurance; lan Crowder of the Automobile Association and Francesca Toffolo of the Association of British Insurers for providing data and other background information. Ken Binmore, David De Meza, Jon Eguida, John McCormack and Ian Tonks have all provided helpful comments.
} 


\section{Introduction}

In this paper we document a significant anomaly in the advertised premiums for car insurance in the UK over the period 2012-13. In particular we show that the premium for comprehensive insurance was substantially less than that for third-party (liability) insurance: since comprehensive insurance automatically includes third-party insurance as well as insurance of the buyer, ceteris paribus it must be strictly more valuable to the buyer and strictly more costly to provide by the insurer. Furthermore, within the comprehensive insurance market, policies with higher deductibles are sometimes more expensive than policies with lower deductibles.

These anomalies require a failure of arbitrage on behalf of buyers: for example, an individual who purchased third-party insurance ${ }^{1}$ could have been strictly better off by choosing to buy comprehensive insurance from the same provider. Correspondingly the anomaly also requires a failure by insurers to provide menus of policies that satisfy an obvious incentive-compatibility constraint, although this need not be irrational so long as consumers persist in their current behaviour.

It might be thought that this anomaly must be a disequilibrium that would quickly be rectified as agents learned about it. In fact the anomaly has persisted for almost two years: our data were collected in June 2012 and June 2013 and the anomaly continues at the time of writing (March 2014). During this period, two long-anticipated changes affected prices. First, in April 2013 the UK law on personal injury claims was changed to reduce the cost of litigation and reduce fraudulent claims and it became harder to avoid insuring a vehicle. ${ }^{2}$ Second, insurers were required to undertake a substantial re-pricing of all insurance products due to the ruling of the European Court of Justice Test Achats, which banned gender-specific pricing. The ECJ ruling was announced on

\footnotetext{
${ }^{1}$ Including one of the authors of this paper.

${ }^{2}$ Until April 2013 it was not necessary to insure an unused vehicle kept off the road and this made it easier to avoid the legal requirement to purchase insurance. Where an accident occurs and the guilty party does not have insurance (or cannot be traced after the accident), pay-outs to the injured party are made by the Motor Insurance Bureau, which raises its funds from a levy on insurance companies, so uninsured vehicles form an extra cost for insurance companies.
} 
1 March 2011, but only became effective on 20 December 2012, allowing insurance companies plenty of time to reconsider optimal pricing policies. Many contemporary publications document the discussions within the insurance industry about how to implement the change. ${ }^{3}$ The ECJ ruling was also widely reported in the British popular press at this time and so many relatively unsophisticated consumers are likely to have read advice that they should shop around to see how prices had changed. Yet the pricing anomaly in 2013 was quantitatively similar to that of 2012.

We dismiss at the outset the possibility that our price data are completely wrong. Our data consist of quotes downloaded by two different researchers at different points of time using dozens of different searches. We have also informally contacted companies to get quotes and later in the paper we provide some corroborative evidence from other publications. The anomaly is too large to be reversed by small differences between quoted prices and prices actually paid.

Nor is it the case that the quotes for third-party insurance apply to a market that does not exist. According to data provided by the Association of British Insurers, ABI (2014), in 2013 the comprehensive (henceforth CP) market was 93 per cent of the market measured by premiums. The remaining seven per cent of policies are either thirdparty (henceforth TP) or third-party, fire and theft (henceforth TPFT). We do not have a breakdown of CP versus TP/TPFT policies by age, but are assured by individuals within the industry that TP/TPFT policies are predominantly purchased by the young, for whom the proportion of the market may be about ten per cent, which is a significant minority of the market. ${ }^{4}$ The ABI data also suggest that $\mathrm{CP}$ is becoming

3 The original Gender Directive is found in Council of the European Union (2004); the relevant ECJ ruling is Case C-236/og Association belge des Consommateurs Test-Achats $A S B L$, initiated on 18 March 2009 and concluded on 1 March 2011. Guidance on the directive was issued on 12 December 2011 (European Commission, 2011). The UK position from July 2012 is described in HM Treasury (2012).

4 The figure of seven per cent non $C P$ insurance is for premiums rather than policies: since our data suggest that TP/TPFT are more expensive than $\mathrm{CP}$, on its own this would suggest that the proportion of TP/TPFT policies would be less than seven per cent. But if TP/TPFT policies are predominantly purchased by just one sector of the market, then that proportion of TP/TPFT in that sector of the market would be more 
more popular: the non-CP share of the market was twice as high in 2003 (fourteen per cent). If we had data showing that the pricing anomaly were long standing, then a falling share of TP/TPFT might indicate that consumers were adjusting to the relative prices of CP and TP/TPFT, although the speed of adjustment would be very slow and the trend for CP policies to form a larger share of the market is also observed in other European countries where (so far as we can ascertain) there is no such pricing anomaly (European Economics, 2009).

One possible reason for third-party policies to be more expensive than corresponding comprehensive policies is a selection effect: suppose that the unobserved risk characteristics of TP policy holders are different from those of $\mathrm{CP}$ policy holders. If this is the case, then we can infer that CP policy holders are lower risk than TP from the prices of the different products, ${ }^{5}$ which is the exact opposite of the separating equilibrium suggested by Rothschild and Stiglitz (1976) where high-risk types buy more insurance, often referred to as the positive correlation property. Chiappori et al. (2006) show that the positive correlation property is robust to changes in the precise assumptions about the insurance market and so forms an appropriate test of the theory, but the review of the empirical literature by Cohen and Siegelman (2010) finds little convincing evidence for adverse selection. Among the papers cited in their review, several find a statistically insignificant negative correlation (Chiappori and Salanié, 2000; Dionne et al. 2001) and one of the specifications in Saito (2006) has a statistically significant negative correlation. However, all of these papers are analysing situations where there is a trade-off: it costs more to buy more insurance, whereas in our data, it costs less to buy more insurance.

The other main model of heterogeneous risk types is that of De Meza and Webb (2001) which suggests that agents have different attitudes to risk: in particular more riskaverse individuals may be naturally more careful and hence less likely to have an accident. The tendency to be low risk is an inherent characteristic of such individuals,

than seven per cent. Back-of-envelope calculations suggest that that the former effect is likely to be slightly smaller than the latter effect.

${ }^{5}$ Our approach here is similar to that of Finkelstein and Poterba (2002), who infer the risk characteristics of different types of annuities from the prices. 
although it could in principle be affected through a moral hazard channel. Evidence for risk heterogeneity has been found in the car insurance market by Cohen and Einav (2007) and elsewhere by Finkelstein and McGarry (2006). But in De Meza and Webb's model there is a pooling equilibrium, where the more-risk-averse/low-risk individuals are happy to buy the same contract as the less-risk-averse/high-risk individuals because the higher utility value of the insurance policy to low-risk individuals offsets the actuarial unfairness arising from the crosssubsidy to high-risk customers.

An alternative approach to tackling the anomaly is that of Campbell (2006) who notes that households may face more complex constraints than financial firms and that apparently surprising behaviour may be due to those constraints. It is not clear what complex constraints exist in our scenario, so it is more likely that the anomaly is due to Campbell's other explanation for consumer behaviour, namely that they make mistakes. These mistakes could be due to bounded rationality along the lines of Kahneman (2003) or could be due to limited information. Our data on car insurance premiums do not allow us to identify the importance of the two explanations, but we shall provide information about the UK car insurance market that suggests both are important.

The rest of our paper fills out the detail of our argument and is structured as follows. In section 2 we describe our data set and the anomaly of TP prices versus $\mathrm{CP}$, also showing that there is no such anomaly within the $\mathrm{CP}$ market. Section 3 reviews some additional information about the UK car insurance market and suggests an explanation for the puzzle. Section 4 concludes.

\section{Data for the UK Car Insurance Market}

The car insurance industry is described in Office of Fair Trading (2011), which suggests that in many ways the industry is highly competitive: the five-firm concentration ratio is only 55 per cent and the "combined ratio", or ratio of claims-plus-administration to premiums was 117 per cent in 2011, suggesting that the industry as a whole made an underwriting loss. Car insurers also receive revenue from the returns on the invested premiums, but in the light of low risk-free returns due to quantitative easing, it is likely that this translated into a loss overall. In recent years new providers such as supermarkets Tesco and Sainsbury's have joined the market. This suggests that the 
market is broadly competitive. Total premiums are just less than one per cent of UK GDP.

Although OFT (2011) had concerns that consumers paid higher prices when they renewed a policy with an existing provider, the OFT's survey reported that 73 per cent of responses had sought quotes from other insurers when renewing and 72 per cent had used an internet search engine (37 per cent had used two or more). There are currently four major internet search engines, of which three have links to an insurance provider and MoneySupermarket is independent. We collected data for firms that provide quotes via MoneySupermarket: some firms do not provide a quote or do not provide a quote for every type of policy. It is often possible to proceed directly from the internet search engine to an electronic form to purchase the insurance, or else the purchase can be made by telephone.

We collected data for male and female policies in 2012 and unisex policies in 2013, for two ages (23 and 44) and for three occupations (solicitors, where the proportion of men and women are approximately equal; civil engineers, who are overwhelmingly male; social service managers, who are overwhelmingly female). Our applications requested insurance cover for a 23-year old with a three-year no-claims bonus, who was single and had no children; 44-year olds with a nine-year no-claim bonus, were married and had two children. Fifteen other pieces of information were required to obtain a quote such as type of car and mileage were held constant across all quotes and we requested quotes for a range of deductibles between zero and $£ 500,{ }^{6}$ although the quotes we received often had a different deductible (as the voluntary deductible is added to a compulsory deductible for many companies).

There are three policy types in the United Kingdom: third party (TP), which is the minimum legal requirement; third party, fire and theft (TPFT) and comprehensive (CP). We have analysed a selection of insurance policy documents to confirm the precise differences between the policies, which is not always obvious from the summary provided by MoneySupermarket. In a representative example the policy document contains seven chapters: all seven chapters apply to comprehensive policies;

\footnotetext{
${ }^{6}$ N.b. in British English a deductible is an "excess".
} 
chapters A (liability insurance), C (fire and theft) and G (driving outside the UK) apply to TPFT; only chapters A and G apply to TP. The key point here is that the benefits of $\mathrm{CP}$ policies strictly exceed the benefits of TPFT, which strictly exceed those of TP. We only collect data for CP and TP: we should expect TPFT to be slightly more expensive than TP; from some less detailed analysis we have done TPFT is sometimes slightly cheaper than TP, consistent with the ranking of prices being anomalous. Nearly all TP quotes from MoneySupermarket had a compulsory zero deductible. This is unsurprising as any claim is paid direct to the injured party, so the insurance company would have to reclaim the deductible from the policy holder, which might prove difficult or expensive. Conversely nearly all CP policies had a minimum deductible: from reading the policy documents we know that this did not apply to the liability (TP) component of a CP policy (chapter $\mathrm{A}$ in the example given).

We summarise the raw data for price quotes in Table 1, which shows that TP premiums are much higher than $C P$.

\section{Table 1 (simple averages of prices) about here}

Although these simple averages are not perfectly comparable because we do not take deductibles into account, they illustrate the broad picture fairly accurately. From the first part of the table we see that for a man aged 23 in 2012 the mean premium was $£ 2,694$, which is a sufficiently large sum of money that we would expect there to be strong incentives to devote effort to finding a lower price. Since the minimum price may be highly idiosyncratic, we give some idea of how much the price could be reduced by reporting the cheapest decile among all of the quotes, which reduces the figure to $£ 1,541$, which is still a substantial sum of money. We note also that young women pay much lower premiums than men and that 44-year olds pay less again, although at age 44 the difference between premiums for men and women is much smaller: in a small number of cases women pay more than men. Unisex premiums in 2013 were lower but this might be due to successful reduction in fraudulent claims as noted in the introduction.

Both TP and CP policies had up to five additional extras, which are either included automatically in the policy or are available for a higher price, which is nearly always reported: the average increments for extras are shown in Table 2. 


\section{Table 2 (information on extras) about here}

If we compare the corresponding $\mathrm{CP}$ and $\mathrm{TP}$ policies from the same provider, we find that the $\mathrm{CP}$ policy always contains weakly more extras automatically than the TP policy. Using the average increment for extras where it is reported, our data suggest that the raw figures in Table 1 under-estimate the price of CP policies by just under $£ 51$ compared to TP policies. Although there is wide variation between companies' prices for a given policy type, the presence of extras does not explain this: some of the cheapest premiums have more extras. ${ }^{7}$

We now turn to a more formal comparison of TP and CP policies. For each policy type we create a data set of the TP policy and lowest deductible CP policy offered by each firm. We then estimate simple regressions of price on a constant and a dummy variable for a policy being TP for three sets of data: (i) the entire sample; (ii) the subsample of firms offering both TP and CP policies (matched pairs); (iii) the sub-sample of matched pairs for those firms whose prices were in the cheapest decile. Our results for Solicitors are reported in Table 3; results for Civil Engineers and Social Service Mangers reported in the Appendix are quantitatively similar.

\section{Table 3 (comparison of TP and CP) about here}

Positive figures in the table denote higher TP than CP prices and the figures are in pounds sterling. These statistics confirm the findings of Table 1: for example a male solicitor age 23 would have to pay one thousand pounds more to have a TP policy. More interesting we see that even buying a TP policy from the same firm would typically cost $£ 1078$ more and most firms would be charging between $£ 803$ and $£ 1432$ for TP. This conclusion is not due to the presence of firms charging very high prices: the firms with the cheapest policies similarly charge much more for TP. Recall that all

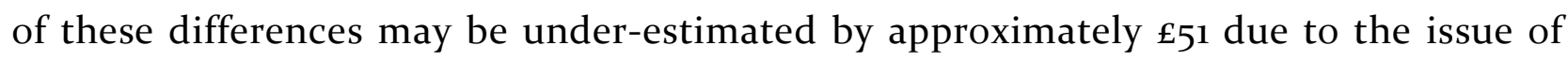
extras. The anomaly is the same for men and women and persists from 2012 to 2013.

\footnotetext{
${ }^{7}$ A cross-section regression of 94 quotes (Female, Civil Engineer, age 23) on a constant and dummies for the five possible extras yields an R-squared of o.o43; none of the coefficients are statistically significant and some have the incorrect sign. The cost of extras does not appear to depend on age, gender or occupation.
} 
We know of no other studies that have collected data similar to our own, but at this point we provide some corroborative evidence for the anomaly. The UK's Automobile Association publishes an index of insurance quotes where CP policies are more expensive than TPFT policies, but this does not compare quotes for exactly the same risks and so the indices are uninformative. We note, however, that the relative price of CP policies to TPFT has fallen: over the period 1994-2004 CP policies were never less than 80 per cent of the price of TPFT and since 2010 they have never been above 75 per cent of the price of TPFT. For the quotes with the best prices the fall has been even more dramatic, from 115 per cent in July 2004 to 68 per cent in 2013. So the evidence from the $\mathrm{AA}$ is that the relative price of $\mathrm{CP}$ policies has fallen substantially in recent years.

A second piece of corroborative evidence is provided by the study of the European car insurance industry by Europe Economics (2009), which compares markets in Europe and the USA. ${ }^{8}$ The study collected price quotes for six hypothetical individual profiles in 2008, three for TPFT and three for CP and again it is impossible to make a perfect comparison. However, profiles 1 (22-year old, three year's driving, no claims) and 5 (21year old, three year's driving, no claims) are very similar on the factors with the largest effect on premiums: the average quote in the UK market for TPFT for profile 1 was $£ 894$ and the average quote for CP for profile 5 was $£ 785$ (figures taken from European Economics, 2009; Table 8.3, p.289, and Table 8.9, p.308). So TPFT was 14 per cent more expensive than CP. Other than Italy (where the market for CP insurance is tiny, only about 1 per cent of the market), no other European market had CP insurance more expensive than TPFT: on average it was 43 per cent lower in the EU.

Since there is an anomaly between the TP and CP parts of the market, what can we say about the CP market, where we have information on deductibles? The deductible consists of a compulsory deductible plus a voluntary deductible: the presence of a compulsory deductible effectively creates a minimum and this was usually strictly positive: for 23-year olds it was most commonly $£ 150$ or $£ 400$ in 2012 and $£ 200$ or $£ 350$

8 Among other things, the report also shows that competition (ie the five-firm concentration ratio) in the UK car industry and combined ratio are similar to those of other markets and so the UK market is not peculiar in other respects. 
in 2013; for 44-year olds the most common minimum deductibles allowed were $£ 100$ or £150 in both 2012 and 2013. ${ }^{9}$

We should expect that the higher the voluntary deductible, the lower the price: a negative price-deductible relationship is the relevant incentive compatibility constraint within the CP market. In our data we observe that this relationship holds most, but not all of the time: a minority of providers charge a higher price for a policy with a voluntary deductible of £10o than for a policy with a voluntary deductible of zero. Table 4 illustrates the proportion of providers for which the policy with the higher deductible has the higher price. The sums of money are not huge: for 23-year olds the additional cost of a £1oo-deductible policy, where positive, averages $£ 9.49$ for men in 2012; $£ 6.14$ for women in 2012 and $£ 6.06$ for unisex in 2013.

\section{Table 4 (anomalous price-deductible policies) about here}

Clearly a policy with a zero deductible and a lower price is strictly superior to a more expensive policy with a deductible of $£ 100$, so the observations which do not satisfy a negative price-deductible relationship are not consistent with conventional models of adverse selection (or any rational informed behaviour). However, unlike the TP-CP comparison, this anomaly is confined to a minority of providers; from the second part of Table 4 we can see that very few of the cheapest providers displayed this anomalous and these were all for 23-year olds in 2012.

Since the proportion of policies that do satisfy the incentive compatibility constraint is large, it is possible that behaviour by most agents within the CP market is consistent with adverse selection models. We are able to say a little more than this, as the ECJ ruling on unisex pricing is a natural experiment resulting in increased asymmetry of information due to the fact that a major risk factor could no longer be used to price

\footnotetext{
9 One of the most important ideas of the adverse-selection models is that firms use deductibles to control the quantity of insurance purchased. Interestingly, if firms are using deductibles in this way, their approach is relatively simple: while the price of a policy depends upon gender and occupation, most firms have the same minimum deductible regardless of these two variables.
} 
policies in 2013. ${ }^{10}$ This increase in asymmetry of contractible information should result in a decrease in the trade-off between price and deductible. To see this consider first Figure 1, which shows the market for male policies in 2012 when firms sell different policies to men and women. Within the male market there is still adverse selection as there are both high-risk and low-risk men. In the Rothschild-Stiglitz version of the market, if the proportion of high risk individuals is high enough, a separating equilibrium is achieved by high risk males buying full insurance (the contract on the $45^{\circ}$ line) and low-risk males buying the partial insurance contract where the indifference curve of the high risk males cuts the low-risk break-even condition for providers. ${ }^{\text {I }}$ On the figure we highlight the difference in the price of the two policies and the difference in the deductible, which should be negative. We are interested in the ratio of the difference in deductible over difference in price ratio,

$$
-\left(\frac{\Delta \text { Deductible }}{\Delta \text { Price }}\right) \equiv-\left(\frac{0-\text { Deductible }^{\text {Low risk }}}{\text { Price }^{\text {High risk }}-\text { Price }^{\text {Low risk }}}\right)
$$

which is the slope of a line drawn between the two contracts.

Figure 1 (price and deductible in the male-only market) about here

Now consider the imposition of unisex pricing, which will introduce two new types: high-risk females and low-risk females. The pricing of female and male policies in 2012 suggests that high-risk females are less risky than high-risk males and it seems reasonable to assume that they are riskier than low-risk males, so they will be an

${ }^{10}$ Finkelstein, Poterba and Rothschild (2009) discuss the possible consequences of banning gender-based insurance in the UK annuity market (where, like the car insurance market, it is compulsory to purchase insurance), but in their model there is no price anomaly. Buzzacchi and Valletti (2005) provides some evidence of the effects of a move in the opposite direction, namely the change to gender-priced car insurance permitted in Italy after 1995. Schmeiser, Störmer and Wagner (2013) discuss other possible consequences of the abolition of gender-based pricing in the European Union.

${ }^{11}$ If the proportion of high risk individuals is low, then the separating contracts cannot be an equilibrium and the equilibrium may not exist at all, although this depends on the responses of firms to each others' contracts (Wilson, 1977) in which case there may be a pooling equilibrium. It is also possible for there to be a separating equilibrium with contracts still obeying the positive correlation property but with cross subsidisation (Miyazaki, 1977; Spence, 1978). 
intermediate risk type. For these three risk types the insurance provider must provide three policies illustrated in Figure 2. Figure 2 is the same as Figure 1 except for the addition of a further break-even condition. ${ }^{12}$

\section{Figure 2 (price and deductible in the unisex market) about here}

From Figure 2 we can see that the trade-off between deductible and price is larger both if we compare high-risk males and low-risk males or high-risk males and high-risk females. The trade-off between high-risk males and low-risk males becomes larger because the old low-risk male policy is no longer available and low-risk males have to buy the new policy where the high-risk female indifference curve cuts the low-risk break-even condition. Since (with indifference curves satisfying the single-crossing property) this is further down the break-even condition, it is clear that the trade-off is now larger.

To compare high-risk males with the high-risk females, note that the contract for highrisk females must lie on the indifference curve for high-risk males at the point shown. Since the indifference curve is convex to the origin, it follows that this new policy also has a higher trade-off.

To see the effect of unisex pricing we estimate regressions for each CP policy type (ageoccupation-gender) of the form

(2) $\quad\left(\right.$ Deductible $_{i, j}-$ Min Deductible $\left._{j}\right)=\beta_{0}+\beta_{1}\left(\right.$ Price $_{i, j}-$ Price $\left._{j}^{\text {Min Deductible }_{j}}\right)+\varepsilon_{i, j}$

where Min Deductible ${ }_{j}$ is the lowest excess allowed by provider $j$, Price ${ }_{j}^{\text {Min Deductible }_{j}}$ is the corresponding price and $\left\{\right.$ Price $_{i, j}$, Deductible $\left._{i, j}\right\}$ are all of the price-deductible combinations offered by provider $j$ for that policy type. Equation (2) is similar to estimating the relationship with fixed effects; given the anomaly already mentioned, we know that there is some reason to suspect non-linearity but, given the small range of deductibles, we do not attempt to identify this.

\footnotetext{
${ }^{12}$ Note, however, that the nonexistence problem becomes more severe in this case, since pairs of cross-subsidising contracts could be profitable deviations from the separating contracts.
} 
Since the price and deductible are presumably set simultaneously by providers on the basis of unobserved random variables also correlated with the error term $\varepsilon_{i, j}$, the least squares estimator of $\beta_{1}$ maybe an inconsistent estimator of the true price-deductible relationship and we do not have any excludable instruments to attempt to identify the trade-off. However, as a check we also estimate

$$
\text { (3) } \quad\left(\text { Price }_{i, j}-\text { Price }_{j}^{\text {Min Deductible }_{j}}\right)=\alpha_{0}+\alpha_{1}\left(\text { Deductible }_{i, j}-\text { Min Deductible }_{j}\right)+\varepsilon_{i, j}^{\prime}
$$

We report our results of the regressions for Solicitors in Table 5: results for other occupations are similar.

\section{Table 5 (price-deductible relationship) about here}

From the first panel of the table, we compare the coefficients for the male and female quotes in 2012 and the unisex quotes in 2013. The trade-off between price and deductible is larger in 2013 for both 23- and 44-year olds, but the effect is neither large nor statistically significant. However, this is estimated for all providers and we know that some firms are offering much higher prices than others: if the prices represent monopoly power, then the break-even constraint is not binding and it may be less important for such firms to separate out the risk types. So in the second panel we repeat the analysis for just those firms whose prices are in the lowest quartile and where separating out the two risk types is presumably more important. The effect for 23 -year olds is now very large - whereas the deductible rises by $£ 1.73$ or $£ 1.34$ for every reduction in premium in 2012, in 2013 it rises by $£ 4.36$, and the difference is statistically significant. We recognise that there may be endogeneity bias, but estimating the regression in the other direction leads to a statistically significant fall in the pricedeductible ratio.

The effect for 44-year olds is smaller and remains statistically insignificant in regression (2). However, this is less surprising. The difference in the level of prices for 44-year old males and 44-year old females from the same provider is small, suggesting that the difference in risk between males and females is very low: it may be that highrisk males are similar risk to high-risk females and similarly for the low risks. In which case, losing the ability to price off gender for 44-year olds makes little difference and hence there is no need to increase the trade-off between price and deductible. 


\section{Discussion and Interpretation}

We now turn to possible explanations of our data. We start with the purchasers of car insurance, since their behaviour is the crux of the matter: why would they buy TP insurance if it were dearer than $\mathrm{CP}$ ? The most obvious reason is that they believe $\mathrm{CP}$ insurance is dearer and are not disabused of this belief when they compare prices. The prior belief is reasonable: ceteris paribus $\mathrm{CP}$ insurance should be dearer. The way that internet search engines are configured, the initial choice is between TP and CP policies and so one does not see prices of the other type of policy. Advice in magazines and on MoneySupermarket's own website does not draw attention to the anomaly. For example, the MoneySupermarket website dated 25 June 2013 had an article listing five ways to reduce one's premium: (i) shop around; (ii) protect one's no-claim discount; (iii) increase security of one's car by keeping it off the road or in a garage; (iv) manage one's policy (e.g. by adjusting reported miles driven so that it is not too high); (v) use telematics (i.e. have a black-box recorder in the car to monitor driving behaviour). The possibility of switching from TP to CP was not mentioned. In fact, one of the most common lines in advice columns says that "Third party, fire and theft cover is usually cheaper than comprehensive cover", with the suggestion that only occasionally can one do better by buying $\mathrm{CP}$ instead of TP.

There is independent evidence that consumers are generally confused about car insurance policies and so consumers may be unclear what they or buying or may not get the best advice possible from car insurers. The most extreme case is "mis-selling" which, in the UK context, is the use by insurance providers of aggressive sales techniques (frequently involving mis-information) to sell products that are unsuitable: one of the companies in our sample, Swinton, was fined $£ 7$ million and required to set aside $£ 11$ million compensation on policies totalling $£ 93$ million during this period (Financial Conduct Authority, 2013).

Confusion may arise due to differences in policies offered by insurers: since insurance companies offer up to five "extras", we know that the policies cover different things. One of the five extras in our data set is "legal cover", but it is probably unclear what this means when using a search engine. FSA (2013) explains that the full name for "legal cover" is Motor Legal Expenses Insurance (MLEI) and that it provides extra legal assistance in recovering losses when the fault is that of another party and there is 
difficulty in claiming from that other party's TP insurance. If the other party is not insured or cannot be traced then the injured party is refunded by the Motor Insurance Bureau, so MLEI is only relevant in a small number of cases where the guilty party is known but the insurer will not pay. However, four-fifths of the 1021 respondents in the FSA's survey of policy holders thought that MLEI paid legal costs when it was the insured party (i.e. themselves) that was at fault rather than the other party. The overall conclusion of the FSA survey was that many purchasers of car insurance did not really know what they had purchased: for example the quote from a respondent described as aged 40-6o years, higher financial confidence, with MLEI: "You see all these options but you don't really know what they are for" (FSA, 2013, p. 15). In further comments in the survey, the FSA noted that those who purchased MLEI tended to be more cautious while those who did not tended to be more optimistic.

This is consistent with the idea that more cautious individuals tend to buy more insurance as in De Meza and Webb (2001) and Cohen and Einav (2007). If we could generalise this to the entire car insurance market, then the most cautious (and hence least risky) individuals would tend to buy CP policies and the least cautious (and hence most risky) individuals would tend to buy TP policies. The division of attitudes towards risk and underlying risk characteristic are the same as in De Meza and Webb (2001), but the lack of understanding prevents all types from joining a pooling equilibrium: instead a plausible prior that TP will be cheaper (which appears not to be contradicted by advice columns) results in the highest risk separating themselves from the lowest risk and buying less insurance. So long as policies were correctly priced on the actual risk, TP would be more expensive than CP.

This brings us to the behaviour of sellers of car insurance. One initial possibility that we dismiss is that the quoted prices on MoneySupermarket are wrong and that the prices actually paid are different. Given the magnitude of the difference in price for TP and $\mathrm{CP}$ policies it is implausible that the ordering of prices actually paid could be reversed. Furthermore it is not clear that firms have any incentive to quote prices which are the reverse of what they actually charge.

Assuming that the advertised prices are indicative of actual prices, insurance companies know that they are offering prices that do not satisfy an incentive compatibility constraint, but so long as the prices reflect the actual risks, they have no 
incentive to change prices: lowering the price of TP policies would result in them being under-priced and hence unprofitable, while raising the price of $\mathrm{CP}$ policies would result in losing market share of the consumers that the insurers most want to attract (i.e. the low risk). Ania, Tröger and Wambach (2002) suggest that car insurers may have bounded rationality and use a different method to price policies, offering a menu of contracts, withdrawing unprofitable contracts and occasionally experimenting with new contacts. So long as consumers are rational and make appropriate choices, the market evolves to a unique equilibrium which is the same as Rothschild and Stiglitz (1976), but Ania, Tröger and Wambach (2002) do not discuss what would happen if consumers' behaviour were also characterised by bounded rationality.

As we have seen, the pricing anomaly is not confined to the comparison between the TP and CP market: there are also a small number of providers who charge more for a higher deductible. As with the TP-CP phenomenon, it is possible that most consumers think that asking for a deductible is a good way to reduce the price: indeed money advice columns explicitly say this. Since the desired voluntary deductible is one of the pieces of information that must be provided on an internet search engine, a consumer would never see the prices for alternative deductibles unless they conducted a selection of searches which would have to include a zero deductible (as there is a negative relationship between price and deductible for all other deductibles). It is possible that only the most risk-averse and hence cautious drivers would ask for a zero deductible, in which case charging a lower price would adequately reflect the risk.

\section{Conclusion}

We have shown that there are substantial, persistent and durable anomalies in the pricing of the UK car insurance market: in particular, CP policies are cheaper than TP policies. This is even true when comparing policies that are otherwise identical (quotes for the same individual with same characteristics for the same car from the same provider). Despite the anomaly, the TP and TPFT policies form a significant minority of the market. There is also evidence for a smaller anomaly within the $\mathrm{CP}$ market in that the price of a policy with a £1oo deductible is less than for one with no deductible. 
Within the $\mathrm{CP}$ market there is evidence for pricing consistent with the adverseselection of the Rothschild-Stiglitz model after the ECJ ruling: if firms had responded to the inability to price separately for the two genders by merely averaging the two policy types, the deductible-price trade-off would have been an average of the male and female trade-offs, but in fact they responded by increasing the deductible-price trade-off for 23-year-olds (where gender is a strong indicator of risk). The fact that CP policies are cheaper than TP policies is so surprising that many readers will have difficulty in believing it. ${ }^{13}$ So it is likely that unsophisticated consumers have similar prior beliefs that $\mathrm{CP}$ policies are more expensive. So long as aversion to risk is negatively correlated with risk type (as in De Meza and Webb, 2001) and car insurers respond merely by offering menus of contracts which are profitable (as in Ania, Tröger and Wambach, 2002), this could result in low risk types buying more insurance and, in the most extreme cases, result in TP policies being more expensive for car insurers due to TP policy holders being so much more risky than CP policy holders. This is appears to be what has happened in the UK car insurance market.

We should expect such an anomaly not to persist for long periods of time, but this anomaly has existed for almost two years in the UK and persisted despite a large shock to the market that might have been expected advice columns in newspapers and magazines to notice the anomaly and draw it to consumers' attention. How much longer the anomaly will last is anyone's guess.

${ }^{13}$ Although only anecdotal, we observe that seminar participants and colleagues have found it difficult to believe. 
Tables and Figures

Table 1: Average car insurance premiums

\begin{tabular}{|l|c|c|c|c|c|c|}
\hline & 2012 & & & & 2013 & \\
\hline & $\begin{array}{c}\text { Male } \\
23\end{array}$ & $\begin{array}{c}\text { Female } \\
23\end{array}$ & $\begin{array}{c}\text { Male } \\
44\end{array}$ & $\begin{array}{c}\text { Female } \\
44\end{array}$ & $\begin{array}{c}\text { Unisex } \\
23\end{array}$ & $\begin{array}{c}\text { Unisex } \\
44\end{array}$ \\
\hline Third-party policies & & & & & & \\
\hline Mean premium & 2694 & 1816 & 797 & 704 & 1894 & 686 \\
\hline Cheapest decile premium & 1541 & 627 & 326 & 269 & 1347 & 345 \\
\hline Comprehensive policies & & & & & & \\
\hline Mean premium & 1533 & 1142 & 453 & 425 & 1122 & 375 \\
\hline Cheapest decile premium & 1047 & 826 & 313 & 309 & 786 & 267 \\
\hline
\end{tabular}

Mean averages are calculated across the entire sample, for all occupations and levels of deductible and are in pounds sterling rounded to the nearest pound. 
Table 2: Average costs of extras where available as an option

\begin{tabular}{|l|l|l|l|}
\hline Extra & $\begin{array}{l}\text { sample } \\
\text { size }\end{array}$ & cost $(£)$ & $\begin{array}{l}\text { proportion of CP policies that } \\
\text { automatically include extra vis-á-vis } \\
\text { corresponding TP policy not } \\
\text { automatically including extra }\end{array}$ \\
\hline windscreen & 1 & 20.00 & $86 \%$ \\
\hline courtesy car & 3 & 18.29 & $86 \%$ \\
\hline breakdown & 71 & 42.41 & $\mathbf{2} \%$ \\
\hline personal accident & 6 & $\mathbf{2 1 . 1 1}$ & $\mathbf{8 2} \%$ \\
\hline legal cover & 57 & $\mathbf{2 7 . 5 0}$ & $\mathbf{0} \%$ \\
\hline
\end{tabular}


Table 3: Comparison of TP and CP prices for Solicitors)

\begin{tabular}{|l|l|l|l|l|l|}
\hline \multicolumn{2}{|l|}{ Solicitors } & All quotes & $\begin{array}{l}\text { Matched } \\
\text { pairs }\end{array}$ & & $\begin{array}{l}\text { Cheapest } \\
\text { only }\end{array}$ \\
\hline Age & Gender, year & $\begin{array}{l}\text { Mean } \\
\text { difference }\end{array}$ & $\begin{array}{l}\text { Mean } \\
\text { difference }\end{array}$ & $\begin{array}{l}\text { Inter-decile } \\
\text { range }\end{array}$ & $\begin{array}{l}\text { Mean } \\
\text { difference }\end{array}$ \\
\hline 23 & Men, 2012 & $\begin{array}{l}1150 \\
(73)\end{array}$ & $\begin{array}{l}1078 \\
(76)\end{array}$ & $803-1432$ & $\begin{array}{l}1359 \\
(286)\end{array}$ \\
\hline & Women, 2012 & $\begin{array}{l}818 \\
(55)\end{array}$ & $\begin{array}{l}775 \\
(59)\end{array}$ & 0-1133 & $\begin{array}{l}695 \\
(224)\end{array}$ \\
\hline \multirow{4}{*}{44} & Unisex, 2013 & $\begin{array}{l}770 \\
(79)\end{array}$ & $\begin{array}{l}790 \\
(77)\end{array}$ & $343-1114$ & $\begin{array}{l}1057 \\
(102)\end{array}$ \\
\hline & Men, 2012 & $\begin{array}{l}384 \\
(24)\end{array}$ & $\begin{array}{l}354 \\
(25)\end{array}$ & $100-556$ & $\begin{array}{l}381 \\
(61)\end{array}$ \\
& Women, 2012 & $\begin{array}{l}302 \\
(24)\end{array}$ & $\begin{array}{l}\mathbf{2 8 7} \\
(22)\end{array}$ & $112-457$ & $\begin{array}{l}279 \\
(52)\end{array}$ \\
\hline & Unisex, 2013 & $\begin{array}{l}308 \\
(34)\end{array}$ & $\begin{array}{l}368 \\
(26)\end{array}$ & $25-487$ & $\begin{array}{l}415 \\
(42)\end{array}$ \\
\hline
\end{tabular}

All figures are in pounds sterling. The first column reports the difference in the mean price of all third-party and all comprehensive policies: sample sizes range from 113 to 143 and standard errors are clustered by provider (of which there are between 78 and 92). The second and third columns are based on price differences between third-party and comprehensive for those providers that quote both and sample sizes range from 34 to 48 . In all cases the comprehensive policy used to compare the third-party and comprehensive policy is the one with the minimum excess (i.e. the highest price). The fourth column uses the subset of the matched pairs data, where prices are in the cheapest quartile. 
Table 4: Proportion of policies with anomalous price and deductible (Solicitors)

\begin{tabular}{|c|c|c|c|}
\hline & Male, 2012 & Female, 2012 & Unisex, 2013 \\
\hline \multicolumn{4}{|c|}{ All policies } \\
\hline Age 23 & $\begin{array}{c}0.377 \\
(0.059)\end{array}$ & $\begin{array}{c}0.300 \\
(0.060)\end{array}$ & $\begin{array}{c}0.179 \\
(0.047)\end{array}$ \\
\hline Age 44 & $\begin{array}{c}0.076 \\
(0.030)\end{array}$ & $\begin{array}{c}0.134 \\
(0.038)\end{array}$ & $\begin{array}{c}0.042 \\
(0.024)\end{array}$ \\
\hline \multicolumn{4}{|c|}{ Cheapest policies } \\
\hline Age 23 & $\begin{array}{c}0.067 \\
(0.067)\end{array}$ & $\begin{array}{c}0.267 \\
(0.118) \\
\end{array}$ & $\begin{array}{c}0 \\
(-)\end{array}$ \\
\hline Age 44 & $\begin{array}{c}\text { o } \\
(-)\end{array}$ & $\begin{array}{c}0 \\
(-)\end{array}$ & $\begin{array}{c}0 \\
(-)\end{array}$ \\
\hline
\end{tabular}

Figures show the proportion of policies where the price for a £100-deductible policy is more expensive than the price for the corresponding zero-deductible policy; standard errors of the proportions are in parentheses to assist comparison of different proportions with each other. Cheapest policies are defined as those in the cheapest quartile. Figures for Civil Engineers and Social Service Managers are very similar and differ mainly due to occasional missing data. 
Table 5: Relationship between price and deductible (Solicitors)

\begin{tabular}{|c|c|c|c|}
\hline & Male, 2012 & Female, 2012 & Unisex, 2013 \\
\hline \multicolumn{4}{|c|}{ Regressions of deductible on price (equation 2 ) - all policies } \\
\hline Age 23 & $\begin{array}{c}-0.978 \\
(0.117) \\
\end{array}$ & $\begin{array}{c}-1.015 \\
(0.108) \\
\end{array}$ & $\begin{array}{c}-1.280 \\
(0.124) \\
\end{array}$ \\
\hline Age 44 & $\begin{array}{l}-2.944 \\
(0.391)\end{array}$ & $\begin{array}{l}-2.969 \\
(0.422)\end{array}$ & $\begin{array}{l}-3.200 \\
(0.626)\end{array}$ \\
\hline \multicolumn{4}{|c|}{ Regressions of deductible on price (equation 2 ) - cheapest policies only } \\
\hline Age 23 & $\begin{array}{c}-1.730 \\
(0.238)\end{array}$ & $\begin{array}{c}-1.342 \\
(0.214)\end{array}$ & $\begin{array}{l}-4.361 \\
(0.514)\end{array}$ \\
\hline Age 44 & $\begin{array}{l}-4.794 \\
(1.035)\end{array}$ & $\begin{array}{l}-3.866 \\
(0.585)\end{array}$ & $\begin{array}{c}-6.121 \\
(3.542)\end{array}$ \\
\hline \multicolumn{4}{|c|}{ Regressions of price on deductible (equation 3 ) - all policies } \\
\hline Age 23 & $\begin{array}{c}-0.273 \\
(0.030)\end{array}$ & $\begin{array}{c}-0.204 \\
(0.026)\end{array}$ & $\begin{array}{l}-0.205 \\
(0.034)\end{array}$ \\
\hline Age 44 & $\begin{array}{l}-0.092 \\
(0.010)\end{array}$ & $\begin{array}{c}-0.085 \\
(0.009) \\
\end{array}$ & $\begin{array}{c}-0.078 \\
(0.009) \\
\end{array}$ \\
\hline \multicolumn{4}{|c|}{ Regressions of price on deductible (equation 3 ) - cheapest policies only } \\
\hline Age 23 & $\begin{array}{c}-0.295 \\
(0.046)\end{array}$ & $\begin{array}{c}-0.194 \\
(0.039)\end{array}$ & $\begin{array}{c}-0.100 \\
(0.032)\end{array}$ \\
\hline Age 44 & $\begin{array}{l}-0.080 \\
(0.011)\end{array}$ & $\begin{array}{l}-0.086 \\
(0.012)\end{array}$ & $\begin{array}{l}-0.035 \\
(0.010)\end{array}$ \\
\hline
\end{tabular}

Each cell shows the parameter estimate from a different regression of the forms specified in equations (2) or (3). Standard errors in parentheses are robust to heteroskedasticity and clustered by provider. Cheapest policies are defined as those in the cheapest quartile. Figures for Civil Engineers and Social Service Managers are very similar. 
Figure 1: Price and deductible in male-only market

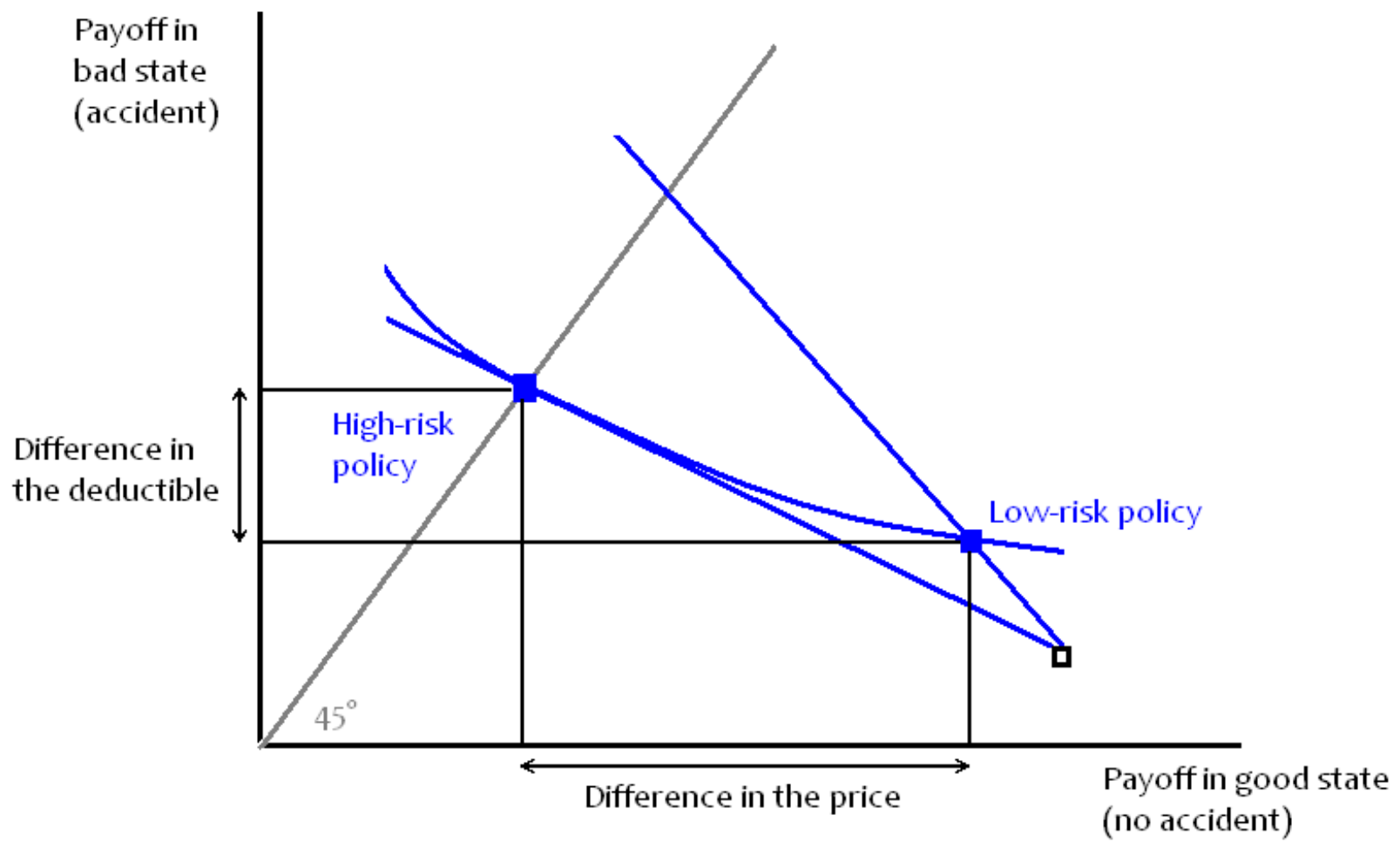


Figure 2: Effect on price-deductible relationship with unisex pricing

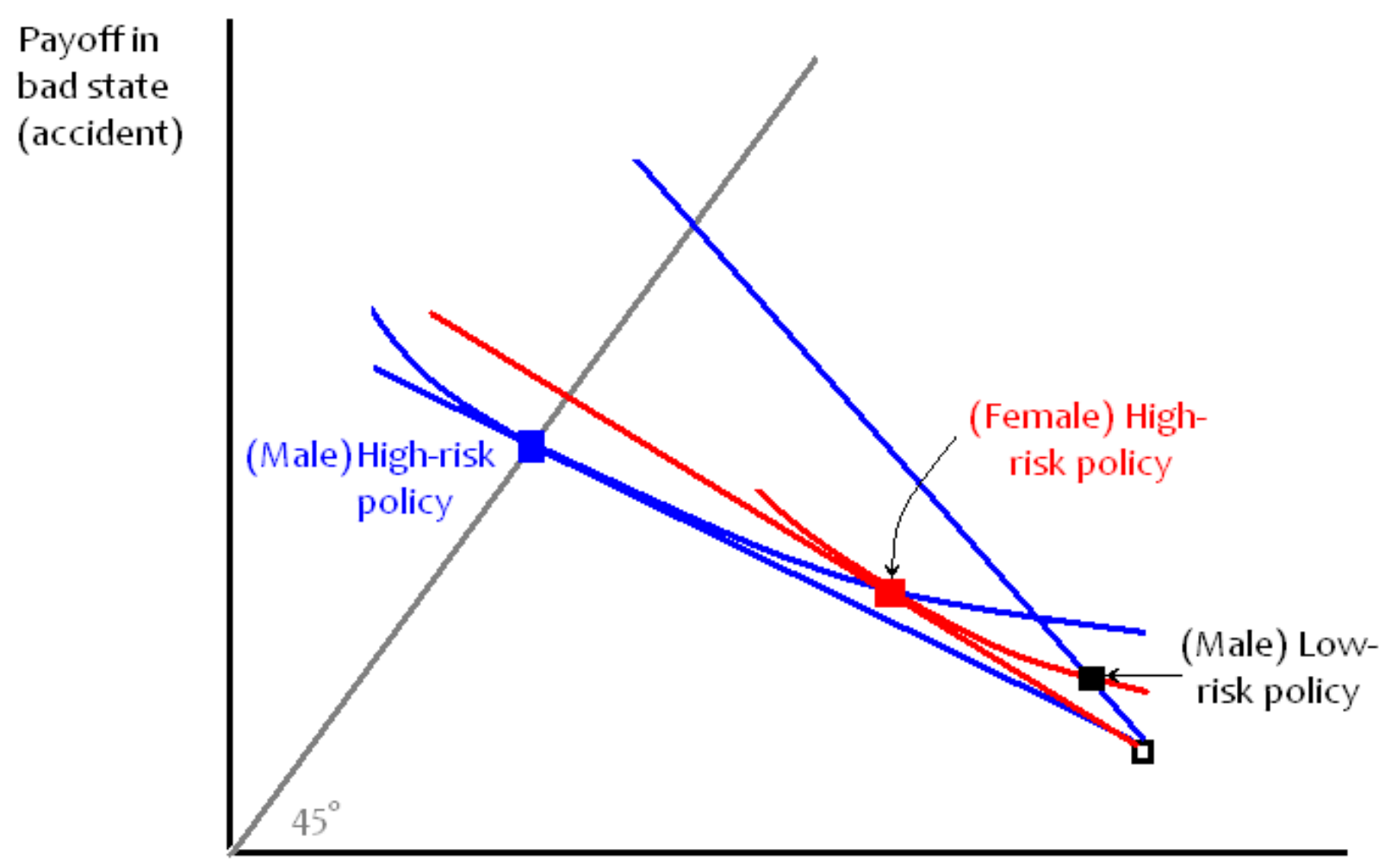

Payoff in good state (no accident) 


\section{References}

Ania, Ana B., Thomas Tröger, and Achim Wambach (2002) "An evolutionary analysis of insurance markets with adverse selection." Games and Economic Behavior 40, pp. 153184 .

Association of British Insurers (2014) General Insurance Statistics (Motor) - Detailed Premium Analysis Table 10.

Buzzacchi, Luigi, and Tommaso M. Valletti (2005) "Strategic Price Discrimination in Compulsory Insurance Markets.” The Geneva Risk and Insurance Review, 30, pp. 71-97. Campbell, John Y. (2006) “Household Finance.” Journal of Finance, 61(4), pp. 1553-1604. Charter of Fundamental Rights of the European Union (2000) Official Journal of the European Communities, $\mathrm{C}_{364 / 01 .}$

Chiappori, Pierre-André and Bernard Salanié (2000) “Testing for Asymmetric Information in Insurance Markets.” Journal of Political Economy, 108(1), pp. 56-78.

Chiappori, Pierre-André, Bruno Jullien, Bernard Salanié, and François Salanié (2006) “Asymmetric Information in Insurance: General Testable Implications.” RAND Journal of Economics, 37(4), pp. 783-798.

Cohen, Alma, and Liran Einav (2007) "Estimating Risk Preferences From Deductible Choice.” American Economic Review, 97(3), pp. 745-788

Cohen, Alma, and Peter Siegelman (2010) "Testing for Adverse Selection in Insurance Markets." Journal of Risk and Insurance, 77(1), pp. 39-84.

Council of the European Union (2004) “Council Directive 2004/113/EC implementing the principle of equal treatment between men and women in the access to and supply of goods and services." Official Journal of the European Union, L373, pp. 37-43.

De Meza, David, and David C. Webb (2001) “Advantageous Selection in Insurance Markets." The RAND Journal of Economics, 32(2), pp. 249-262.

Dionne, Georges, Christian Gouriéroux and Charles Vanasse (2001) "Testing for Evidence of Adverse Selection in the Automobile Insurance Market: A Comment.” Journal of Political Economy, 109(2), pp. 444-473. 
Europe Economics (2009) Retail Insurance Market Study, MARKT/2008/18/H Final Report. (Europe Economics, Chancery Lane, London).

European Commission (2011) "Guidelines on the application of Council Directive 2004/113/EC to insurance, in the light of the judgment of the Court of Justice of the European Union in Case C-236/o9 (Test-Achats).” Brussels, C(2011) 9497.

European Court of Justice (2011) Case C-236/o9 Association belge des Consommateurs Test-Achats ASBL.

Financial Conduct Authority (2013) “Final Notice to Swinton Group Limited”.

Financial Services Authority (2013) "Motor legal expenses insurance” Consumer Market Research 88.

Finkelstein, Amy, and Kathleen McGarry (2006) "Multiple Dimensions of Private Information: Evidence from Long-Term Care Insurance Market.” The American Economic Review, 96(4), pp. 938-958.

Finkelstein, Amy, and James Poterba (2002) "Selection Effects in the United Kingdom Individual Annuities Market.” The Economic Journal, 112(476), pp. 28-50.

Finkelstein, Amy, James Poterba and Casey Rothschild (2009) "Redistribution by insurance market regulation: Analyzing a ban on gender-based retirement annuities" Journal of Financial Economics, 91, pp.38-58.

HM Treasury (2012) "UK response to the 1 March European Court of Justice ruling that insurance benefits and premiums after 21 December 2012 should be gender-neutral: Government response" (London: HM Treasury).

Kahneman, Daniel (2003) "Maps of Bounded Rationality: Psychology for Behavioral Economics" The American Economic Review, 93(5), pp. 1449-1475.

Miyazaki, Hajime (1977) “The rat race and internal labour markets." Bell Journal of Economics, 8, pp. 394-418.

Office of Fair Trading (2011) "Private Motor Insurance: Summary of responses to the OFT's call for evidence” OFT 1397. 
Rothschild, Michael, and Joseph Stiglitz (1976) "Equilibrium in Competitive Insurance Markets: An Essay on the Economics of Imperfect Information.” The Quarterly Journal of Economics, 9o(4), pp. 629-649.

Saito, Kuniyoshi (2006) "Testing for Asymmetric Information in the Automobile Insurance Market Under Rate Regulation." Journal of Risk E Insurance, 73(2), pp. 335356.

Schmeiser, Hato, Tina Störmer and Joël Wagner (2013) "Unisex Insurance Pricing: Consumers' Perception and Market Implications." The Geneva Papers, , pp. 1-29.

Spence, Michael (1978) "Product differentiation and performance in insurance markets." Journal of Public Economics, 10, pp. 427-447.

Wilson, Charles (1977) "A model of insurance markets with incomplete information." Journal of Economic Theory, 16, pp. 167-207. 


\section{Appendix for Online Publication Only}

\section{Table A1. Comparison of TP and CP premiums}

\begin{tabular}{|c|c|c|c|c|c|}
\hline \multicolumn{6}{|c|}{ Social Service Managers } \\
\hline & & All quotes & Matched pairs & & Cheapest only \\
\hline Age & Gender, year & $\begin{array}{c}\text { Mean } \\
\text { difference }\end{array}$ & $\begin{array}{c}\text { Mean } \\
\text { difference }\end{array}$ & $\begin{array}{c}\text { Inter-decile } \\
\text { range }\end{array}$ & $\begin{array}{c}\text { Mean } \\
\text { difference }\end{array}$ \\
\hline \multirow[t]{3}{*}{23} & Men, 2012 & $\begin{array}{l}1337 \\
(117)\end{array}$ & $\begin{array}{l}1243 \\
(103)\end{array}$ & $921-1570$ & $\begin{array}{l}1500 \\
(366)\end{array}$ \\
\hline & Women, 2012 & $\begin{array}{l}941 \\
(61)\end{array}$ & $\begin{array}{l}900 \\
(62)\end{array}$ & $0-1249$ & $\begin{array}{c}678 \\
(265)\end{array}$ \\
\hline & Unisex, 2013 & $\begin{array}{l}815 \\
(85) \\
\end{array}$ & $\begin{array}{r}821 \\
(82)\end{array}$ & $375-1306$ & $\begin{array}{l}1043 \\
(123) \\
\end{array}$ \\
\hline \multirow[t]{3}{*}{44} & Men, 2012 & $\begin{array}{l}446 \\
(25)\end{array}$ & $\begin{array}{l}409 \\
(25)\end{array}$ & $133-588$ & $\begin{array}{l}394 \\
(88) \\
\end{array}$ \\
\hline & Women, 2012 & $\begin{array}{l}360 \\
(24)\end{array}$ & $\begin{array}{l}336 \\
(23)\end{array}$ & $138-525$ & $\begin{array}{l}278 \\
(72)\end{array}$ \\
\hline & Unisex, 2013 & $\begin{array}{l}338 \\
(35) \\
\end{array}$ & $\begin{array}{l}396 \\
(29)\end{array}$ & $46-536$ & $\begin{array}{l}443 \\
(51)\end{array}$ \\
\hline \multicolumn{6}{|c|}{ Civil Engineers } \\
\hline & & All quotes & Matched pairs & & Cheapest only \\
\hline Age & Gender, year & $\begin{array}{c}\text { Mean } \\
\text { difference }\end{array}$ & $\begin{array}{c}\text { Mean } \\
\text { difference }\end{array}$ & $\begin{array}{l}\text { Inter-decile } \\
\text { range }\end{array}$ & $\begin{array}{c}\text { Mean } \\
\text { difference }\end{array}$ \\
\hline \multirow[t]{3}{*}{23} & Men, 2012 & $\begin{array}{l}1283 \\
(112)\end{array}$ & $\begin{array}{l}1177 \\
(97)\end{array}$ & $878-1534$ & $\begin{array}{c}1355 \\
(296)\end{array}$ \\
\hline & Women, 2012 & $\begin{array}{l}821 \\
(56)\end{array}$ & $\begin{array}{l}792 \\
(60)\end{array}$ & $0-1165$ & $\begin{array}{l}705 \\
(230)\end{array}$ \\
\hline & Unisex, 2013 & $\begin{array}{l}804 \\
(90)\end{array}$ & $\begin{array}{l}799 \\
(85)\end{array}$ & $400-1195$ & $\begin{array}{c}738 \\
(205)\end{array}$ \\
\hline \multirow[t]{3}{*}{44} & Men, 2012 & $\begin{array}{l}378 \\
(25) \\
\end{array}$ & $\begin{array}{l}352 \\
(25) \\
\end{array}$ & $83-581$ & $\begin{array}{l}367 \\
(74) \\
\end{array}$ \\
\hline & Women, 2012 & $\begin{array}{l}304 \\
(24) \\
\end{array}$ & $\begin{array}{l}285 \\
(23) \\
\end{array}$ & $97-490$ & $\begin{array}{r}225 \\
(59) \\
\end{array}$ \\
\hline & Unisex, 2013 & $\begin{array}{l}331 \\
(35)\end{array}$ & $\begin{array}{l}391 \\
(29)\end{array}$ & $29-529$ & $\begin{array}{l}442 \\
(44)\end{array}$ \\
\hline
\end{tabular}

Figures in the first column are the difference in the mean price of all third-party and all comprehensive policies: sample sizes range from 113 to 143 and standard errors are clustered by provider (of which there are between 78 and 92). Figures in the second and third columns are based on price differences between third-party and comprehensive for those providers that quote both and sample sizes range from 34 to 48. In all cases the comprehensive policy used to compare the third-party and comprehensive policy is the one with the minimum excess (i.e. the highest price). The fourth column uses a subset of the matched pairs data using only. 
Table A2: Relationship between price and deductible: different occupations (Civil Engineers)

\begin{tabular}{|c|c|c|c|}
\hline & Male, 2012 & Female, 2012 & Unisex, 2013 \\
\hline \multicolumn{4}{|c|}{ Regressions of deductible on price (equation 2) - all policies } \\
\hline Age 23 & $\begin{array}{c}-1.021 \\
(0.101)\end{array}$ & $\begin{array}{l}-1.052 \\
(0.105)\end{array}$ & $\begin{array}{c}-1.310 \\
(0.141)\end{array}$ \\
\hline Age 44 & $\begin{array}{l}-3.567 \\
(0.530)\end{array}$ & $\begin{array}{l}-3.878 \\
(0.490)\end{array}$ & $\begin{array}{l}-3.767 \\
(0.635)\end{array}$ \\
\hline \multicolumn{4}{|c|}{ Regressions of deductible on price (equation 2 ) - cheapest policies only } \\
\hline Age 23 & $\begin{array}{c}-1.584 \\
(0.276)\end{array}$ & $\begin{array}{c}-1.344 \\
(0.240)\end{array}$ & $\begin{array}{l}-3.590 \\
(0.393)\end{array}$ \\
\hline Age 44 & $\begin{array}{l}-3.840 \\
(0.536)\end{array}$ & $\begin{array}{l}-4.023 \\
(0.592)\end{array}$ & $\begin{array}{l}-10.900 \\
(2.990)\end{array}$ \\
\hline \multicolumn{4}{|c|}{ Regressions of price on deductible (equation 3 ) - all policies } \\
\hline Age 23 & $\begin{array}{l}-0.290 \\
(0.034)\end{array}$ & $\begin{array}{l}-0.207 \\
(0.027) \\
\end{array}$ & $\begin{array}{c}-0.228 \\
(0.030) \\
\end{array}$ \\
\hline Age 44 & $\begin{array}{l}-0.089 \\
(0.010)\end{array}$ & $\begin{array}{l}-0.088 \\
(0.009)\end{array}$ & $\begin{array}{c}-0.088 \\
(0.009)\end{array}$ \\
\hline \multicolumn{4}{|c|}{ Regressions of price on deductible (equation 3 ) - cheapest policies only } \\
\hline Age 23 & $\begin{array}{c}-0.331 \\
(0.046) \\
\end{array}$ & $\begin{array}{c}-0.190 \\
(0.039) \\
\end{array}$ & $\begin{array}{c}-0.158 \\
(0.032)\end{array}$ \\
\hline Age 44 & $\begin{array}{l}-0.100 \\
(0.014)\end{array}$ & $\begin{array}{l}-0.088 \\
(0.011)\end{array}$ & $\begin{array}{l}-0.056 \\
(0.005)\end{array}$ \\
\hline
\end{tabular}

Each cell shows the parameter estimate from a different regression of the forms specified in equations (2) or (3). Standard errors in parentheses are robust to heteroskedasticity and clustered by provider. Cheapest policies are defined as those in the cheapest quartile. 
Table A3: Relationship between price and deductible: different occupations (Social Service Managers)

\begin{tabular}{|c|c|c|c|}
\hline & Male, 2012 & Female, 2012 & Unisex, 2013 \\
\hline \multicolumn{4}{|c|}{ Regressions of deductible on price (equation 2 ) - all policies } \\
\hline Age 23 & $\begin{array}{l}-1.088 \\
(0.182)\end{array}$ & $\begin{array}{l}-1.190 \\
(0.181)\end{array}$ & $\begin{array}{l}-1.326 \\
(0.110)\end{array}$ \\
\hline Age 44 & $\begin{array}{l}-3.186 \\
(0.509)\end{array}$ & $\begin{array}{l}-3.335 \\
(0.502)\end{array}$ & $\begin{array}{l}-3.626 \\
(0.692)\end{array}$ \\
\hline \multicolumn{4}{|c|}{ Regressions of deductible on price (equation 2 ) - cheapest policies only } \\
\hline Age 23 & $\begin{array}{c}-1.815 \\
(0.280)\end{array}$ & $\begin{array}{c}-1.437 \\
(0.240)\end{array}$ & $\begin{array}{c}-2.107 \\
(0.904)\end{array}$ \\
\hline Age 44 & $\begin{array}{l}-4.668 \\
(1.035)\end{array}$ & $\begin{array}{l}-4.239 \\
(0.585)\end{array}$ & $\begin{array}{l}-5.069 \\
(1.254)\end{array}$ \\
\hline \multicolumn{4}{|c|}{ Regressions of price on deductible (equation 3) - all policies } \\
\hline Age 23 & $\begin{array}{l}-0.228 \\
(0.027)\end{array}$ & $\begin{array}{c}-0.170 \\
(0.022)\end{array}$ & $\begin{array}{c}-0.235 \\
(0.029)\end{array}$ \\
\hline Age 44 & $\begin{array}{l}-0.076 \\
(0.010)\end{array}$ & $\begin{array}{l}-0.080 \\
(0.009)\end{array}$ & $\begin{array}{c}-0.083 \\
(0.009)\end{array}$ \\
\hline \multicolumn{4}{|c|}{ Regressions of price on deductible (equation 3 ) - cheapest policies only } \\
\hline Age 23 & $\begin{array}{c}-0.298 \\
(0.044)\end{array}$ & $\begin{array}{l}-0.209 \\
(0.039) \\
\end{array}$ & $\begin{array}{c}-0.174 \\
(0.031) \\
\end{array}$ \\
\hline Age 44 & $\begin{array}{l}-0.094 \\
(0.011)\end{array}$ & $\begin{array}{l}-0.085 \\
(0.010)\end{array}$ & $\begin{array}{c}-0.061 \\
(0.009)\end{array}$ \\
\hline
\end{tabular}

Each cell shows the parameter estimate from a different regression of the forms specified in equations (2) or (3). Standard errors in parentheses are robust to heteroskedasticity and clustered by provider. Cheapest policies are defined as those in the cheapest quartile. 